\author{
Mikołaj Sobkowiak \\ Adam Mickiewicz University \\ al. Niepodległości 4 \\ 61-874 Poznań, Poland
}

\title{
Can phonemes be considered troublemakers? The case of the Danish /r/
}

\begin{abstract}
The acquisition of the Danish sound system can be a difficult task for both native and non-native speakers. This paper is an attempt at showing the ways in which $/ \mathrm{r} /$ contributes to the system's overall complexity. It is suggested that $/ \mathrm{r} /$-related difficulties in Danish are due to the impact $/ \mathrm{r} /$ has on the neighboring sounds and, as a result, on the relations between graphemes, phonemes and sounds. Several phenomena connected with the presence of $/ \mathrm{r} /$ in various contexts are presented to exemplify the above statement, including r-coloring (i.e. the change of the quality of the neighboring vowel), the fusion of $/ \mathrm{r} /$ with neighboring vowels and the interactions between $/ \mathrm{r} /$ and $/ \mathrm{\partial} /$, resulting in a change of vowel length and/or the assimilation of [ə]. The analysis focuses mainly on the grapheme-sound relations and the ways $/ r$ / affects the discrepancy between Danish orthography and pronunciation.

Keywords: Danish pronunciation, Danish orthography, /r/
\end{abstract}

\section{Introduction}

From a linguist's point of view Danish is a fascinating language for a number of reasons, but for learners of Danish it is predominantly the 
complexity of its sound system that makes it particularly hard to understand and acquire.

Typologically Danish is an inflectional-fusional language (though with a tendency to move towards isolating languages, cf. Basbøll 2005: 8) with a rather simple inflectional morphology. Syntactically speaking, Danish is an SVO language with relatively little word order variation, especially in comparison to languages like Polish (cf. Sobkowiak 2011). In terms of phonological features, Danish is, with its 15 consonant and 11 vowel phonemes (cf. Grønnum 2007), what can be referred to as a vowel-dominated language that is moderately rich in phonemes (cf. Maciejewski 1999: 23).

Being a North Germanic/(Mainland) Scandinavian language ${ }^{1}$, Danish is very closely related to Swedish and Norwegian, which translates into a relatively high (though not complete) mutual comprehensibility between the three languages (cf. Basbøll 2005: 7). Interestingly, the Mainland Scandinavian languages' mutual understandability is asymmetrical, Danish being the hardest one to understand for fellow Mainland Scandinavians, especially Swedes (cf. Gooskens et al. 2010a and literature cited there), for reasons that scholars are not unanimous about.

A somewhat obvious explanation of the mentioned asymmetry would be that Danish is intrinsically more difficult to understand than Swedish. However, the findings of Gooskens et al. (2010a) do not seem to confirm this hypothesis. Other data suggest that the mentioned intelligibility-related Danish-Swedish asymmetry may be accounted for by the impact speech rate has on the intelligibility of speech (Schüpert et al. 2016) or by the orthography-pronunciation relationship in Swedish and Danish (cf. Gooskens et al. 2010b). Yet another explanation may be that Danish pronunciation has been

\footnotetext{
${ }^{1}$ The term North Germanic, as used e.g. in Henriksen \& van der Auwera (1994), includes Danish, Swedish, Norwegian, Icelandic and Faroese. The same group of languages is sometimes referred to as Nordic languages (e.g. Basbøll 2005 and Vikør 2002), while Danish, Swedish and Norwegian are sometimes called Scandinavian or Mainland Scandinavian languages (cf. Basbøll 2005: 6). See also Schab (2009) for a more detailed study of how the terms Nordic and Scandinavian are used.
} 
undergoing constant changes over the past decades (cf. Grønnum 2007) and that among the Scandinavian languages, "Danish is the Scandinavian language that has moved farthest away from its Common Scandinavian roots" (Henriksen/van der Auwera 1994: 6).

What is certain, however, is that spoken Danish is not only hard to understand for fellow Scandinavians and other foreigners but also hard to acquire for the Danes themselves. There seems to be evidence that Danish children acquire their mother tongue slower than children with other mother tongues (cf. Bleses et al. 2008, Trecca et al. 2015).

The complexity of the Danish language's sound system has been the subject of numerous anecdotes and considerable portions of mockery, the sources of the latter ranging allegedly from $16^{\text {th }}$-century Swedes (cf. Basbøll 2005: 82-83) to 21 ${ }^{\text {st }}$-century Norwegian comedians (cf. Gooskens et al. 2010b: 1023). In May 2017 one of Copenhagen's language schools posted a meme on social media that has gone viral, where advice is given on "how to pronounce any Danish word". This includes tips like "ignore this letter", "speak as if you're drunk", "make some funny mouth shape here", "say this as fast as possible", "swallow your tongue here" or "this part always sounds like ooehll" ". This is just some evidence of the stereotypes about the Danish language and Danish pronunciation ${ }^{3}$.

Outside of anecdotes and research in mutual comprehensibility among Scandinavians, several factors seem to be mentioned particularly frequently in discussions on why acquiring the Danish sound system is a rather difficult task. Most of these factors are of a purely linguistic nature, e.g. the Danish language's "extremely rich vowel system" (Basbøll 2005: 8) that includes the particularly

https://www.facebook.com/kbhsprogcenter/photos/a.476540172383770.96047.442655929 105528/1359318730772572/?type=3\&theater. [Last accessed: 30.09 .2017 ].

${ }^{3}$ See Schab/Sobkowiak (2016) for an account of various stereotypes about the Danish language and of what challenges Polish learners of Danish (may) encounter when trying to acquire Danish pronunciation. 
problematic rounded front vowels and (glottalized) vowels with $s t \phi d^{4}$. Other problematic factors are frequent sound reductions, consonant clusters, closed syllables as well as sounds like the so-called soft $d^{5}$ and, last but not least, the r-sound (Basbøll 2005: 8, Grønnum 2007: $15)$.

Reading, writing and understanding Danish words correctly can be difficult for foreigners because "the correspondence between natural spoken Danish and orthography is remarkably poor" (Hansen 2005: 1628). The Danish orthography is sometimes described as "difficult and inconsequent" (Janikowski 1990: 7) and many learners of Danish end up having an orthography-influenced pronunciation. This is often the case when the orthography-sound relations in a learner's native language are much simpler than in Danish (cf. Bigailaite 2010: 108).

Among the extralinguistic factors, the speaker's age and how much effort is put into speaking clearly are often named (cf. Janikowski 1990: 234), as "[t]here is a considerable distance between distinct pronunciation [...] and everyday pronunciation in informal situations" in Danish (Hansen 2005: 1628).

In the following sections I will try to demonstrate how the Danish $/ \mathrm{r} /$ contributes to the overall complexity of the language's sound system and in particular to the discrepancy between the Danish orthography and pronunciation. First, however, the reader needs to gain a basic understanding of the Danish vowel system, a brief description of which is provided in section 2 .

\footnotetext{
${ }^{4}$ The Danish phenomenon of $s t \phi d$ can be briefly defined as "laryngealization, a kind of creaky voice which characterizes certain syllable rhymes under certain conditions" (Grønnum/Basbøll 2003). It is also said to resemble "a glottal stop without complete closure that occurs with long vowels and sonorants under certain conditions" (Haberland 1994: 317-318).

${ }^{5}$ I.e. the dental semivowel [ð].
} 
2. The basics of the Danish vowel system

\subsection{The Danish vowel rows}

Based on their articulatory features, Danish full vowel sounds are divided into what is referred to, especially in course books in Danish pronunciation, as 3 vowel rows (e.g. Rasmussen 2005, Thorborg 2001), as presented below.

Tab. 1 The Danish vowel rows

\begin{tabular}{ccc}
\hline i-row & -row & $u$-row \\
\hline$[\mathrm{i}]$ & {$[\mathrm{y}]$} & {$[\mathrm{u}]$} \\
{$[\mathrm{e}]$} & {$[\varnothing]$} & {$[\mathrm{o}]$} \\
{$[\varepsilon]$} & {$[\propto]$} & {$[\mathrm{o}]$} \\
{$[æ]$} & {$[\Subset]$} & {$[\mathrm{p}]$} \\
{$[\mathrm{a}]$} & & {$[\Lambda]$} \\
{$[\mathrm{a}]$} & &
\end{tabular}

The front unrounded vowel sounds [i e æ a] and the vowel [a] make up the so-called i-row (i-rakken), while the y-row (y-rakken) consists of the following rounded front vowels: [у $\varnothing \propto \mathrm{E}]$. The $u$-row (u-rakken), on the other hand, is comprised of rounded back vowels,

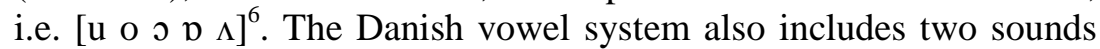
that only occur in unstressed syllables, referred to as "schwa sounds" (Haberland 1994: 319) or "neutral vowels" (Basbøll 2005: 143), i.e. [ə] and [e].

Except for the aforementioned two vowels that only occur in unstressed syllables and $\left[\mathrm{a} \Lambda\right.$ ], which are almost always short ${ }^{7}$, Danish vowel sounds can, depending on the phonological context, occur in one of three variants - as a short vowel, a long vowel and a (long) glottalized one, a so-called st $\phi d$ vowel, cf. (1):

\footnotetext{
${ }^{6}$ For a more detailed classification of Danish vowels see e.g. Basbøll (2005), Janikowski (1990).

${ }^{7}$ They can, however, "be lengthened across word boundaries as a consequence of schwa-assimilation (...), but this is irrelevant for the phonemic analysis" (Basbøll 2005: 49).
} 
(1) a. mis [mis], mile ['mi:lə], mil ['mi:'l]

b. lyt! ['lyd], lyse ['ly:sə], lys ['ly:'s]

c. foto ['fot ${ }^{\mathrm{s}} \mathrm{o}$, mole ['mo:lə], sol ['so:?1]

As noted by Basbøll (2005: 79), both vowel length and stød can be contrastive in Modern Danish, cf. (2).

(2) a. hule ['hu:lə], hulde ['hulə]

b. hul ['hu:'1], huld ['hul']

\subsection{Primary pronunciation and vowel gliding}

In most cases Danish long and $s t \phi d$ vowels have the so-called primary pronunciation (Rasmussen 2005: 42), the term referring to the relation between graphemes and vowel sounds. If a grapheme in a given word corresponds to a vowel that, based on the context, is long or has st $\phi d^{9}$, the vowel is in most cases pronounced "the same way as it is written" (Rasmussen 2005: 42). In practice this means that the vowel quality corresponds to that of the name of the given letter in the Danish alphabet. This way the following pairs of graphemes and their default/primary pronunciation variants can be formed:

(3) a. $\left.\langle\mathrm{i}\rangle \quad\left[\mathrm{i}: \mathrm{(}^{(}\right)\right] \quad$ mile ['mi:lə], mil ['mi:'1]

b. $\langle\mathrm{e}\rangle \quad\left[\mathrm{e}:\left({ }^{2}\right)\right]$ sene ['se:nə], Hven ['ve:?n]

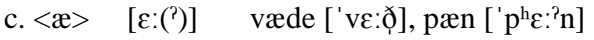

d. $\langle\mathrm{a}\rangle \quad\left[\mathfrak{*}:\left({ }^{3}\right)\right] \quad$ tale ['ts:lə], man ['mæ:?n]

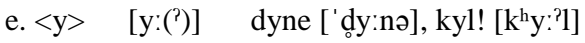

f. $\langle\varnothing\rangle \quad\left[\varnothing:\left({ }^{2}\right)\right] \quad$ søde ['s $\left.\varnothing: \partial\right\rceil$, Møn ['m $\left.\varnothing: ? n\right]$

g. $\langle\mathrm{u}\rangle \quad\left[\mathrm{u}:\left({ }^{(}\right)\right] \quad$ bule ['bu:lə], sus ['su:? $\left.\mathrm{s}\right]$

h. $\langle\mathrm{o}\rangle \quad\left[\mathrm{o}:\left({ }^{2}\right)\right]$ mole ['mo:la], os ['o:?s]

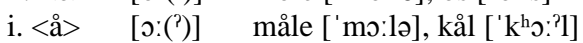

\footnotetext{
${ }^{8}$ The examples stem from Basbøll (2005: 45-47).

${ }^{9}$ For the sake of clarity one could formulate the following, extremely simplified and somewhat incomplete, set of rules for vowel length and $s t \phi d$ occurrence in Danish: (i) a vowel can be long or have st $\phi d$ if it occurs in a stressed syllable and is followed by one consonant or no consonants at all, (ii) a vowel occurring in a stressed syllable and followed by two or more consonants is most likely to be short and (iii) vowels in unstressed syllables are never long or have st $\phi d$ (cf. Rasmussen 2005: 37-38). For a more detailed exploration of the nature and function of $s t \phi d$ see Basbøll (2005).
} 
Graphemes corresponding to short vowels are unlikely to be pronounced with the vowel qualities mentioned in (3), as the realization of short vowels is more often than not connected with what Danish phoneticians describe as vowel gliding (Rasmussen 2005) or vowel lowering (Thorborg 2001). The glide/lowering means that a given grapheme is most likely to be pronounced using a short vowel that is located one step down within the same vowel row as far as the i- and y-rows are concerned or at least two steps down in the case of the u-row (cf. Rasmussen 2005: 43-44). In (4) some typical pairs of graphemes and their pronunciation variants in the case of vowel gliding/lowering are presented:

(4) $\quad$ a. $\langle\mathrm{i}\rangle \quad$ [e] lidt ['led]

b. $\langle\mathrm{e}\rangle \quad[\varepsilon] \quad$ vend! ['ven']

c. $\langle a>$ [a] mand ['man']

d. $\langle a\rangle$ [a] mappe ['mabə]

e. $\langle æ>\quad[\varepsilon] \quad$ væske ['vesg̊]

f. $\langle y\rangle \quad[\varnothing] \quad$ lyst ['løsd]

g. $\langle\varnothing\rangle \quad[œ] \quad$ søndag ['sœn'da]

h. $\langle\mathrm{u}\rangle \quad[\mathrm{o}] \quad$ bugt ['bog̊d]

i. $\langle 0\rangle \quad[0] \quad$ ost ['osd]

j. $\langle 0\rangle \quad[\mathrm{p}] \quad$ skov ['sgopor]

k. $\langle 0\rangle \quad[\Lambda] \quad \operatorname{kost}\left[{ }^{\mathrm{h}} \mathrm{h}^{\mathrm{h}} \Lambda \mathrm{sd}\right]$

1. $<a ̊>\quad$ ånd [ $[\Lambda]$

The above examples account for some of the discrepancies between the orthographic form of Danish words and their pronunciation but they also illustrate some instances of deviations from the general rules presented above. For example, the extent of the glide in the case of $\langle a\rangle$ and $\langle 0\rangle$ is context-dependent (cf. (4c), (4d), (4i), (4j) and (4k)), while vowel gliding in the form mentioned above does not always occur (4e), cf. Rasmussen (2005:39-40).

As it will become apparent in section 3.2, the extent of vowel gliding/lowering in Modern Danish is not limited to the contexts mentioned above. 
3. The Danish $/ \mathrm{r} /$ and its influence on the neighboring sounds

3.1. The phoneme and its variants

The Danish phoneme /r/ has three basic, context-dependent variants. Syllable-initially it is realized as [в], as it is when $/ \mathrm{r} /$ occurs prevocalically after a consonant (cf. (5a) and (5b), respectively).

(5) a. rive ['ьі:б], ryge ['ьу:ə], rose ['ьо:sə],

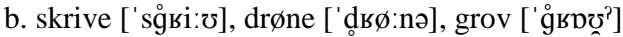

The articulatory status of $[\mathrm{в}]$ is not entirely clear - while most scholars classify it as a fricative (e.g. Basbøll 2005: 62, Haberland 1994: 320, Hansen 2005: 1627, Janikowski 1990: 161), it is considered by some to be a non-lateral approximant (Basbøll 2005: 62) or a liquid consonant (Grønnum 2007: 114f.) ${ }^{10}$.

There is no unanimity, either, with regards to [ь]'s place of articulation. Most scholars consider it to be a uvular sound (e.g. Basbøll 2005: 62, Janikowski 1990: 161), but it is also sometimes described as supra-pharyngeal (Grønnum 2007: 102) or velar (Hansen 2005: 1627).

[в] is commonly known to be voiced (cf. Grønnum 2007: 115, Haberland 1994: 320, Janikowski 1990: 161), although, according to Erik Hansen (2005: 1627), it is "mostly unvoiced".

If the consonant preceding [в] happens to be an aspirated stop $\left(\left[\mathrm{p}^{\mathrm{h}}\right],\left[\mathrm{t}^{\mathrm{s}}\right]\right.$ or $\left.\left[\mathrm{k}^{\mathrm{h}}\right]\right)$ or $[\mathrm{f}]$, the sound corresponding to $/ \mathrm{r} /$ gets at least partly devoiced and /r/ is therefore realized as [б] (Grønnum 2007: 115, Janikowski 1990: 161), cf. (6):

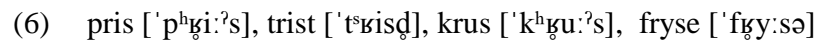

As presented below in (7), after stressed full vowels, the Danish /r/ is realized as $[\mathrm{p}]$ - a "non-syllabic central retracted neutral vowel (pharyngeal glide)" (Basbøll 2005: 63) or semivowel (Grønnum 2007:

${ }^{10}$ Grønnum uses the term liquid consonants (likvider) as an umbrella term for laterals and r-sounds (Grønnum 2007: 202). 
115) that forms diphthongs with the preceding full vowels (Basbøll 2005:66) or fuses with them (see section 3.3). The sound is also known as vocalic $r$ (Hansen 2005: 1627, 2006: 97) and can have st $\phi d$, cf. (7).

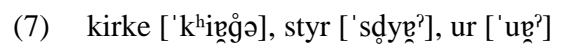

While the variants of Danish /r/ are, despite the terminological discrepancies, not particularly hard to pronounce and the general rules of their distribution are rather clear, the presence of $/ \mathrm{r} /$ in Danish words has serious consequences for their pronunciation, as it can affect the neighboring sounds in several ways that will be presented in the following sections.

\subsection{R-coloring}

The signature feature of the Danish / $\mathrm{r} /$ is that it can affect the quality of the neighboring sounds, which is called the influence of $r$ ( $r$ påvirkning) by e.g. Grønnum $(1998,2007)$ and Rasmussen (2005) or $r$-coloring ${ }^{11}$ (Basbøll 2005). Hans Basbøll defines the phenomenon as

a whole series of sound changes in Danish, which are mirrored in synchronic phonological rules, all with the effect that the vowel in question, when it is adjacent to an $/ \mathrm{r} /$, becomes 'one step closer' to the low pharyngeal vowel (Basbøll 2005: 149)

and points out that "it is clearly not an automatic coarticulation phenomenon, but something which must be learnt" (Basbøll 2005: 150).

Hans Basbøll presents the effect of r-coloring in terms of inputoutput relations between segments (2005: 151), while Nina Grønnum also provides several generalizations about the influence $/ \mathrm{r} /$ has on its

\footnotetext{
${ }^{11}$ Basbøll (2005) uses the British English spelling variant, i.e. $r$-colouring. For the sake of consistency with American English spelling applied throughout this paper, the term is spelled $r$-coloring here.
} 
vowel neighbors (1998: 243-244), which can be summarized in the following way:

1. If a vowel is at all influenced by $/ \mathrm{r} /$, the influence applies to both the long and short vowel.

2. Postvocalic /r/ affects only low and semi-low vowels; long and short vowels are influenced in the same way.

3. /i: i y: y o: o/ are not influenced by prevocalic or postvocalic $/ \mathrm{r} / \mathrm{s}$

4. The influence of prevocalic $/ \mathrm{r} / \mathrm{can}$ be different across generations (e.g. the younger generations pronounce /u: $\mathrm{u} /$ after /r/ as [o: o], while older ones do not).

5. $/ \varepsilon: /$ and $/ \varepsilon /$ are influenced by $/ \mathrm{r} /$ differently and the realization of both of them is also dependent on the right-hand context.

While it is clearly the presence of the phoneme $/ \mathrm{r} /$ and its different realizations that affect the way /r/-adjacent phonemes are realized, for many average language users the phoneme-sound relations in Danish may appear to be too abstract and complex. In fact, many learners of Danish, especially those whose attempts at acquiring spoken Danish take place outside of a purely academic setting, are often not even aware of the nature of these relations. What is of greater importance to such learners, are grapheme-sound relations (even though they are in fact merely a result of the underlying phoneme-sound relations).

Translated into grapheme-sound relations, r-coloring means that $<r>$-adjacent graphemes corresponding to vowels can be pronounced as vowels located even further down the respective vowel rows than it is in the case of vowel gliding with no r-coloring (cf. Rasmussen 2005:41). Thus, a series of grapheme-vowel pairs for $/ \mathrm{r} /$-adjacent contexts can be formed, some of which are presented in (8) below.

\begin{tabular}{|c|c|c|c|}
\hline \multirow{7}{*}{ (8) } & a. $\langle i\rangle$ & {$[\varepsilon]$} & briste ['bьвsdə] \\
\hline & b. $\langle a\rangle$ & [a] & sparke ['sba:g̊a] \\
\hline & c. $\langle\mathrm{e}\rangle$ & [æ] & gerne ['g̊æennə] \\
\hline & d. $\langle æ>$ & {$[\varepsilon]$} & ræv ['ьย:?থ] \\
\hline & e. $\langle\mathfrak{x}\rangle$ & [æ] & ærter ['æędø] \\
\hline & f. $\langle\mathfrak{x}\rangle$ & [a] & rænke ['вауg̊ə] \\
\hline & g. $\langle y\rangle$ & [œ] & bryst [' 'bьœsd] \\
\hline
\end{tabular}




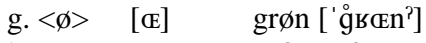

$$
\begin{aligned}
& \text { h. }\langle\mathrm{u}\rangle \text { [о] ruf ['воf] }
\end{aligned}
$$

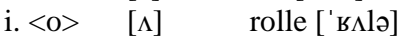

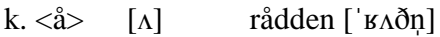

As demonstrated in (8), r-coloring can add an extra step or two down the relevant vowel row compared to the $/ \mathrm{r} /$-free examples of vowel gliding provided in section 2.2, example (4). In some cases, however, the glide can be extended to as many as 4 steps down the row, e.g. in /re/-sequences, where /e/ corresponds to a short vowel:

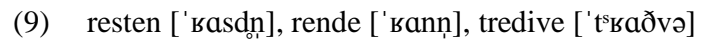

\subsection{The fusion of $/ \mathrm{r} /$ and vowel}

Hans Basbøll mentions another phenomenon, or at least a special case of $r$-coloring, where the vowel and the following vocalic $r$ in some contexts are "fused, that is to say, collapsed to one segment" (Basbøll 2005: 152). This happens when the vowel in question is low (cf. Grønnum 2007: 115). Consider the following examples:

(10) spark ['sba:g̊], kort ['khp:do $]$, årle ['p:lə]

As presented in (10), the full vowels have actually undergone vowel gliding extended by means of r-coloring and fused with the following $/ \mathrm{r} /$. Translating the above into grapheme-sound relations

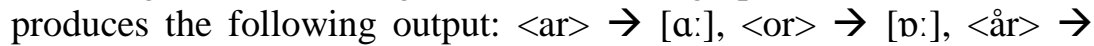
[b:]). The vowels have undergone what is referred to as compensatory lengthening and thus become long (cf. Basbøll 2005: 154, Grønnum 2007: 152). This seems to be at least partly in line with Erik Hansen's observation that "[i]n normal modern pronunciation, vocalic [r] is seldom articulated but manifests itself as a tinting of the preceding vowel" (Hansen 2005: 1627).

\subsection{The /r/-drop}

Apart from affecting the neighboring vowels' quality and fusing with them, the Danish /r/ can also be pronounced weaker or even be 
omitted in certain contexts. According to Nina Grønnum (2007: 115116), this can happen when /r/ precedes unstressed pretonic full vowels (11a), although not word-initially (11b).

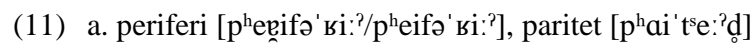
b. raritet [ваi' $t^{\mathrm{s}} \mathrm{e}:$ ? $\mathrm{d}$ ]

When /r/ occurs syllable-finally in a syllable directly preceding a stressed syllable, it can "disappear completely without leaving any trace" (Grønnum 2007), for which Nina Grønnum has provided the following examples:

(12) portrætter [ $\left.\mathrm{p}^{\mathrm{h}} \mathrm{o}^{\prime} \mathrm{t}^{\mathrm{s}} \mathrm{Gad} \mathrm{o} \mathrm{c}\right]$, vurdere [vu'de:? $\left.\mathrm{p}\right]$, sortere [so' $\mathrm{t}^{\mathrm{s}} \mathrm{e}:$ ? $\left.\mathrm{e}\right]$

As Grønnum (2007: 116) also points out, /r/ can be omitted when followed by a post-tonic full vowel:

(13) giro ['6i:o], Eros ['e:As]

It is worth noticing, however, that this is most likely to occur in borrowings from other languages, as in words of Danish origin vowels in unstressed syllables usually get reduced to [ə] and in some cases to [r] (cf. section 3.5).

3.5 Interactions between $/ \mathrm{r} /$ and $/ \mathrm{\partial} /$

Apart from being one of the most frequently occurring phonemes in Modern Danish (cf. Schachtenhaufen 2010), the Danish /o/ is of special interest to phoneticians and phonologists due to its frequent assimilations and reductions ${ }^{12}$, which are considered to be one of the factors making the Danish sound system difficult to acquire.

One of the contexts, where schwa-assimilation occurs, is when it is $/ \mathrm{r} /$-adjacent, in which case /a/ is realized as [e]. According to Ruben Schachtenhaufen, it is "widely accepted that schwa is realized as $[\mathfrak{e}]$ in

\footnotetext{
${ }^{12}$ As pointed out by Janikowski (1990: 232), both the assimilation and reduction of schwa in Danish are sometimes collectively referred to as schwa-assimilation. Other scholars, like e.g. Schachtenhaufen (2010), see the two as separate phenomena.
} 
structures like /rə rər ər/" (Schachtenhaufen 2007: 68). As observed by Hans Basbøll, "[t]he subtype of schwa-assimilation which has the pharyngeal neutral vowel $[\mathrm{e}]$ as its result, is obligatory in Modern Standard Danish" (Basbøll 2005: 311).

Among Ruben Schachtenhaufen's examples of interactions between $/ \mathrm{r} /$ and schwa, however, one can find the word $\emptyset$ stergade pronounced as ['øsdəgæ:ð]. In this case the /r/ seems to be dropped without affecting $/ \partial /$, which seems to be in contrast with Hans Basbøll's observation quoted above (cf. Schachtenhaufen 2007: 68).

As presented below, word-final <er> (/or/), which is common for many Danish singular and plural nouns ((14a) and (14b), respectively) as well as most verbs in the present tense $(14 \mathrm{c})$, is pronounced $[\mathfrak{e}]$.

(14) a. svensker ['svensg̊g], maler ['mæ:le], hammer ['hame]

b. bælter ['belde], masker ['masg̊g], buler ['bu:le]

c. læser ['le:se], undrer ['ondogre], måler ['mo:le]

Hans Basbøll sees this as a special case of $/ \mathrm{r}$ / fusing with vowels and calls it schwa+r-fusion (Basbøll 2005:151). His explanation of the phenomenon is that [ə] assimilates to the post-vocalic realization of $/ \mathrm{r} /$, i.e. [e], which, in turn, is subsequently deleted (ibid.).

The assimilation of schwa also occurs in word-final /ra/ sequences, e.g.

(15) brødre [' 'ьююðке], mødre ['тøдке], bladre ['blaðье], skildre ['sg̊eldье]

In such cases [ə] assimilates to [в] and is manifested as [е] but the two segments do not fuse, as /r/ occurs prevocalically and is realized as [в]. The first two examples in (15) are plural forms of nouns, the singular forms of which end in <er> like the examples in (14a).

Analogically, word-final /rər/ is pronounced [вв] - schwa assimilates to and fuses with the final $/ \mathrm{r} /$ (i.e. [e] ) and the first $/ \mathrm{r} /$ of the sequence is realized as [в]. This is the case for present tense forms of the remaining two examples in (15), which are verbs, i.e. bladrer, skildrer.

Nouns whose singular forms end in <er $>$ have plural forms ending in 〈ere>, in which case the <ere> sequence is pronounced [er], as the 
first schwa assimilates to and fuses with the following / $\mathrm{r} /$ and the final schwa assimilates to the thus created [e], cf. (16a). The same applies to comparative forms of adjectives and adverbs ending in <ere> (16b).

(16) a. svenskere ['svensg̨̊e], malere ['mæ:lę], blendere ['blendę]

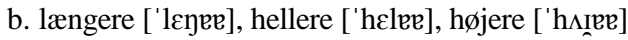

Hans Basbøll points out that "[ $[\mathrm{e}]$ assimilates completely to a preceding $[\mathrm{a}]$ or $[\mathrm{p}]$ - but not to other full vowels" (Basbøll 2005: 311), hence:

(17) $\operatorname{vare}(r)[$ 'va(:)aa], hårdere ['hp(:)pp]

According to Ruben Schachtenhaufen (2007: 68), "an [ь]influenced schwa" can also be subject to reduction. As he points out, this happens regularly, even in clear speech, hence words with final <ere > are often pronounced with $[\mathrm{e}]$ rather than $[\mathrm{ev}]$ at the end, e.g.

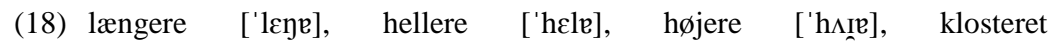
['klısded]/['klısdised]

The aforementioned word-final reductions of [ee] to [e] sometimes lead to homophony between e.g. singular and plural forms of nouns, e.g.:

(19) dansker ['dansg̊ge], danskere ['dansg̊g(ve)]

Homophonic relations occurring due to the fusion and assimilation of $/ \mathrm{r} /$ and $/ \mathrm{\partial} /$ are not limited to the above - a sound sequence obtained this way can even represent four different words, e.g.:

(20) lure, luer, lurer, luger ['lu:e] (Grønnum 2007: 52)

\section{Conclusions}

The aim of this article was to present the ways in which /r/ contributes to the overall complexity of the Danish sound system. For the sake of potential non-Danish speaking readers I have provided some 
elementary linguistic data about Danish in general as well its vowel system in sections 1 and 2 .

As demonstrated in section $3.1, \mathrm{r} / \mathrm{r}$ can be realized in spoken Danish as one of the three context-dependent variants or not realized at all (cf. section 3.4). The variants themselves are not problematic for articulatory reasons and the contexts in which they occur are easily distinguishable, but the presence of $/ r /$ has a substantial influence on the pronunciation of Danish words in several other ways.

$/ \mathrm{r} /$-adjacency has an effect on vowel quality in that it triggers $\mathrm{r}$ coloring and thus extends vowel gliding further down the relevant vowel row. As a result, the number of vowel sounds in which a grapheme corresponding to a vowel can potentially be realized as in speech is increased. Moreover, the extent of the vowel glide is not the same for each of the vowel rows (nor is it the same for all vowels within a row) and there are a number of exceptions from the general rules (cf. section 3.2).

The impact of $/ \mathrm{r} /$ on neighboring sounds can also be that of tinting the vowel quality and fusing with the preceding vowel, in which case $/ \mathrm{r} /$ is actually not realized in speech, even though it changes the vowel's quality. The distribution of this phenomenon, however, is restricted to contexts where $/ \mathrm{r} /$ occurs after [a] and [p]. If the vowel in question is short, it undergoes compensatory lengthening (cf. section 3.3).

The neutral vowel schwa is also affected by /r/. In contexts where it follows $/ r /$, it gets assimilated to it and the entire sequence is realized as [вв]. When schwa precedes $/ \mathrm{r} /$, the two segments are fused and pronounced [e]. In word-final <ere> ([ev]) sequences, one of the /r/-affected schwas can be reduced, which sometimes leads to homophonic relations between different lexemes or even different grammatical forms of the same lexeme (cf. section 3.5).

The above data shows that $/ \mathrm{r} /$ is a significant factor with regards to the Danish sound system's complexity. /r/-adjacency has an impact on both vowel quality and length, while the phoneme itself is not always realized in speech. /r/-related phenomena contribute significantly to the discrepancy between Danish orthography and pronunciation, 
making the Danish orthophonic rules less manageable and less predictable.

In view of the above, the answer to the question formulated in this paper's title is Yes - the Danish / $\mathrm{r} / \mathrm{can}$ be considered quite a troublemaker.

\section{References}

Basbøll, H. (2005). The Phonology of Danish. Oxford: Oxford University Press.

Bigailaite, N. (2010). Danskncer udtale hos udlandinge - et realistisk mål eller en illusion? (=Københavnerstudier i tosprogethed bind 50). København: Københavns Universitet, Humanistisk Fakultet.

Bleses, D. (et al.). (2008). Early vocabulary development in Danish and other languages: A CDI-based comparison. Journal of Child Language 35, 619-650.

Gooskens, Ch. (et al.) (2010a). Is Danish an intrinsically more difficult language to understand than Swedish? [In:] B. Heselwood, C. Upton (eds.). Proceedings of Methods XIII. Papers from the Thirteenth International Conference on Methods in Dialectology, 2008 (=Bamberger Beiträge zur Englischen Sprachwissenschaft 54) (pp. 163-173). Frankfurt am Main: Peter Lang.

Gooskens, C. (et al.) (2010b). Is spoken Danish less intelligible than Swedish? Speech Communication 52, 1022-1037. [available at:] http://www.sciencedirect.com/science/article/pii/S0167639310001093.

Grønnum, N. (1998). Fonetik og fonologi. Almen og dansk. København: Akademisk Forlag.

Grønnum, N. (2007). Rødgrød med fløde. København: Akademisk Forlag.

Grønnum, N., Basbøll, H. (2003). Stød and length in Standard Danish: Experiments in laboratory phonology. Proceedings of the 15th International Congress of Phonetic $\begin{array}{llll}\text { Sciences, } & \text { Barcelona } & \text { 2003, 455-458. }\end{array}$ https://www.internationalphoneticassociation.org/icphsproceedings/ICPhS2003/papers/p15_0455.pdf [last accessed 30.09.2017]

Haberland, H. (1994). Danish. [In:] E. König, J. Van der Auwera (eds.). The Germanic Languages (pp. 313-348). London/New York: Routledge.

Hansen, E. (2005). The standard languages and their systems in the 20th century V: Danish. [In:] O. Bandle et al. (eds). The Nordic Languages. Volume 2 (pp. 16261634). Berlin/New York: Walter de Gruyter.

Hansen, E. (2006). Damonernes port. Materiale til studiet af dansk sprog. København: Hans Reitzels Forlag.

Henriksen, C., van der Auwera, J. (1994). The Germanic Languages. [In:] E. König, J. Van der Auwera (eds). The Germanic Languages (pp. 1-18). London/New York: Routledge. 
Janikowski, K. (1990). Podręcznik wymowy duńskiej. Wrocław: Wydawnictwo Uniwersytetu Wrocławskiego.

Maciejewski, W. (1999). Świat języków (=Wielka Encyklopedia geografii świata 14). Poznań: Wydawnictwo Kurpisz.

Rasmussen, J. (2005). Sig det med takt og tone. Dansk fonetik i teori og praksis. Poznań: Wydawnictwo Naukowe UAM.

Schab, S. I., Sobkowiak, M. (2016). „Odbijający się czkawką sen złośliwego lingwisty”. O postrzeganiu języka duńskiego i trudnościach w jego przyswajaniu. Folia Scandinavica Posnaniensia 20, 187-204.

Schab, S. I. (2009). Skandynawski czy nordycki? Krótkie studium uzusu. Acta SuecoPolonica 15, 205-213.

Schachtenhaufen, R. (2007). Realiseringen af schwa i spontan dansk tale. Master's thesis. København: Københavns Universitet, Institut for Nordiske Studier og Sprogvidenskab.http://schwa.dk/filer/Schwa_speciale.pdf [last accessed 29.09.2017]

Schachtenhaufen, R. (2010). Schwa-assimilation og stavelsesgrænser. NyS 39, pp. 6492. http://schwa.dk/filer/Schachtenhaufen NyS 39.pdf [last accessed 29.09.2017]

Schüpert, A. (et al.) (2016). Why is Danish so difficult to understand to fellow Scandinavians? Speech Communication 79, 47-60. http://www.let.rug.nl/gooskens/pdf/publ speechcom 2016.pdf [last accesssed: 30.09.2017]

Sobkowiak, M. (2011). When $16^{\text {th }}$-century Polish poetry meets modern Danish syntax. A study of an odd case. Folia Scandinavica Posnaniensia 12, 305-314.

Thorborg, L. (2001). Dansk udtale i praksis - med. Rytmisk grammatik. København: Akademisk Forlag.

Trecca, F. (et al.) (2015). When too many vowels impede language processing: The case of Danish. Poster session presented at $40^{\text {th }}$ Annual Boston University Conference on Language Development, Boston, USA.

Vikør, L. S. (2002). The Nordic language area and the languages in the north of Europe. [In:] O. Bandle et al. (eds). The Nordic Languages. Volume 1 (pp. 1-12). Berlin/New York: Walter de Gruyter. 